应 例

血管造影が鑑別診断上有用であった空腸平滑筋肉腫の 1 例

\begin{tabular}{|c|c|c|c|c|c|c|c|c|c|}
\hline 中 & 神 & 一 & 二 & E 村 & 雄 & 次 & 前 & 田 & 正 \\
\hline 神 & 谷 & 順 & 横 & 井 & 俊 & 平 & 安 & 井 & 健 \\
\hline 宮 & 田 & 完 & 向 & 山 & 憲 & 男 & 犬 & 飼 & 偉 \\
\hline 松 & 田 & 真佐男 & 豊 & 田 & 澄 & 男 & 松 & 本 & 隆 \\
\hline 早 & 川 & 直 和 & 鈴 & 分 木 & 雄 & 彦 & & & \\
\hline
\end{tabular}

\title{
A CASE REPORT OF A LEIOMYOSARCOMA OF THE JEJUNUM, DIAGNOSED WITH SELECTIVE ANGIOGRAPHY
}

Kazuhito NAKAGAMI, Yuji NIMURA, Shoji MAEDA, Junichi KAMIYA, Shunpei YOKOI, Kenzo YASUI, Kanji MIYATA, Norio MUKOYAMA, Hidenori INUKAI, Masao MATSUDA, Sumio TOYODA, Takatoshi MATSUMOTO, Naokazu HAYAKAWA and Takehiko SUZUKI 1 st Department of Surgery, Nagoya University School of Medicine, Nagoya (Director : Prof. Yohtaro Iyomasa)

小湯原発の悪性腫湯は比較的むれな疾患であり，特異的な症状のないこと，解剖学的な 制約から椧㚗が困難なこと，また諸家の認識のそしいことなどの理由により，従来より術 前診断の困難な予後下良な疾患とされてきた。

癌腫ではその病理学的特性から狭品ないしは閉塞をきたしやすく，此較的早期に臨床症 状を呈することが多いが，肉腫ことに平滑筋肉腫でははとんどが腫瘤型の発育を示すため 経過が潜行性であり，臨床症状をきたしにくく，徒って睡場の猡死による消化管出血や渴 重皘あるいは瘇晹が高度に発有し腹部腫瘤を呈するようになってはじめて来院するような 症例が殆んどである。しかも上述のよらな理由により術前適確に診断される症例は極めて まれであった。

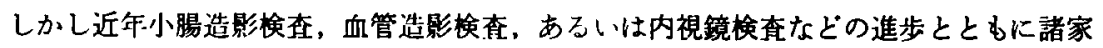
の小腸疾患に対する関心の高まりなとにより適確に術前診断のなされた症例の報告例む堌 加してきた。

私共も最近 54 歳 男子で左上腹部腫癌を主訴とし，某病院で上部消化管造影， CT, 超

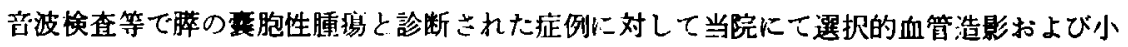
腸二重造影恰査を施行し、ことに血管造影娭査所見から術前に空腸平滑筋肉腫と診断し得 た症例を释験したので，その概晋とよもに，土に診断を中心として若下の文塥的考察を加 シ報告する。

\section{蝫言}

小腸の悪性鄠凘は特異的な症状むなく，診断手技の困 難なこと，また諸家の認識のそしいこともあり従来より
早期診断の困難な子後不良な疾患とされてきた。術前に なんとか存在診断がなされてもその貝的䛦断まで正確に なされたよらな症例の報告は数少ない。 
最近私共は他医より膆腫㻛と診断され釈介された患者 に対し，小腸ファイベースコピー，小腸二重造影法，選 択的血管造影法沈どを施行し術前に空腸平滑筋肉腫と診 断しえた 1 手術例を経験したのでその概要とともに若干 の文献的考察を加え報告する。

\section{应例}

患者：山○房○，54歳，男子。

主新：左上腹部腫痹

家族歴・既往歷：特記すべきものなし。

現病霆：1980年 8 月，自分で左上腹部の腫瘤に気付い た. おさえると不快感を覚えたので某病院を受診し，消 化管造影検查，CT，超音波検査，血管造影検査などで

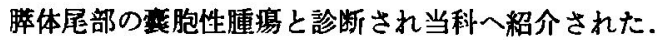

入院時現应：身長 $165 \mathrm{~cm}$ ，体重 $63 \mathrm{~kg}$ ，栄䖯良，眼球・ 服検結膜異常なし．血圧160/92 $\mathrm{mmHg}$ ，脈拍72/分, 左上腹部に小児頭大弹性硬の腫㻤を触知したが王痛，可動性 はなかった，胸部は異常なく，表在性リンバ節る触知せ お. 直腸指診にても異常を認めず.

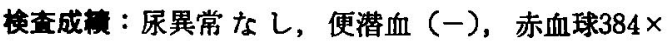
$10^{4}$ ，白血球6,000, $\mathrm{Hb} 12.1 \mathrm{~g} / \mathrm{dl}, \mathrm{Ht} 34.2 \%$, 血小板 $26.5 \times 10^{4}$, 肝機能正常. 血清蛋白 $6.9 \mathrm{~g} / \mathrm{dl}, \mathrm{CEA} 1.9 \mathrm{mg} /$ $\mathrm{dl}$, 心電図巽常なし，胸部X線にて左肺尖部汇陳旧性結 核房巣あり。

\section{上部消化管造影模查所見}

仰㭱位二重造影像では胃の大弯後照に厷沉な环排像が みられ、また Treitz 勒帯部より近位空腸にかけて軽度 の伸展像がみられた．しかし両者とる粘膜像には明らか な病的所見はみられなかった（図1）。

\section{CT 所見}

CT では膀体尾部と思われる部位に巨大な腄慮陰影 がみられた。内部はやや不均一で比較的 density む低い 嗹場と考えられた（図2).

\section{超音波换查所見}

腫瘤は一部で不均一な充実性の部分があるものの塞胞 性の要素が強いやはり膵体尾部由来の腫㻛と診断された (図 3 ).

選択的血管造影検査では造影が不充分のため適確な所 見が得られず以上のごとき所見より前医にては膵体尾部 より発生した衰胞性腫汪として当科に紹介された。

\section{造択的血管造影所見}

当科にて阿度血管造影検查を施行した。腹腔動脈造影 では，膵背動脈より feeding された腫陽血管の一部が みられた（図 4)。上腸間膜動脈造影では近位空晹動脈

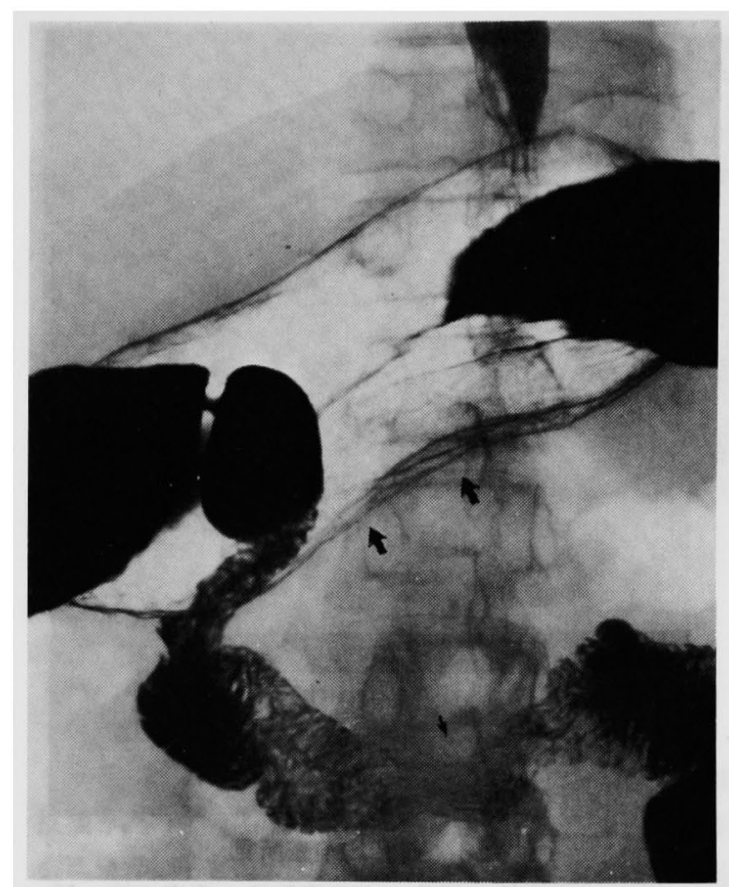

図 1 上部消化管造影模查所見

胃の大弯後壁に広汎な压排像がみられ，また近位空 腸に軽度の伸展像がみられる。

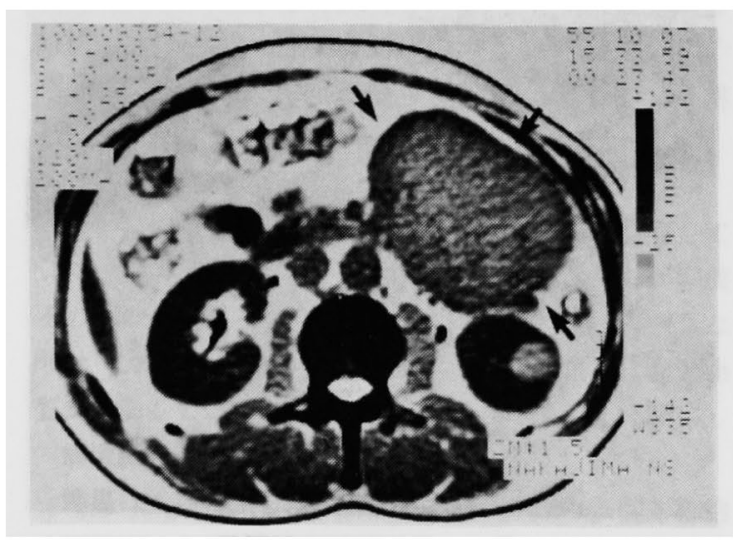

図 2 CT 所見

左上腹部に，愺尾部に連続する上らな巨大董瘤陰影 がられる。

領域に厷沉な腫場陰影がみられた。空腸動脈は内下方に 圧排され，辺縁では血管增生に富むが中心部では 1，2 本の腫場血管がみられるものの血管陰影は非常にそしか った (図5).

静脈相でも辺縁の濃染像が著明であり，また上晹間膜 


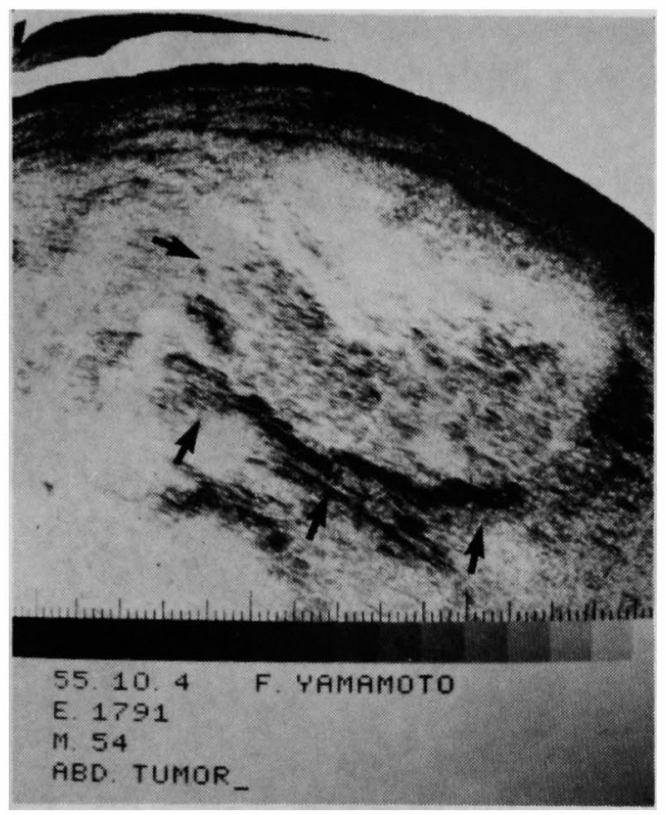

图 3 超音波换查所見

不均一で充実性の部分のある衰胞性の要素の強い腫 埸と診断された。

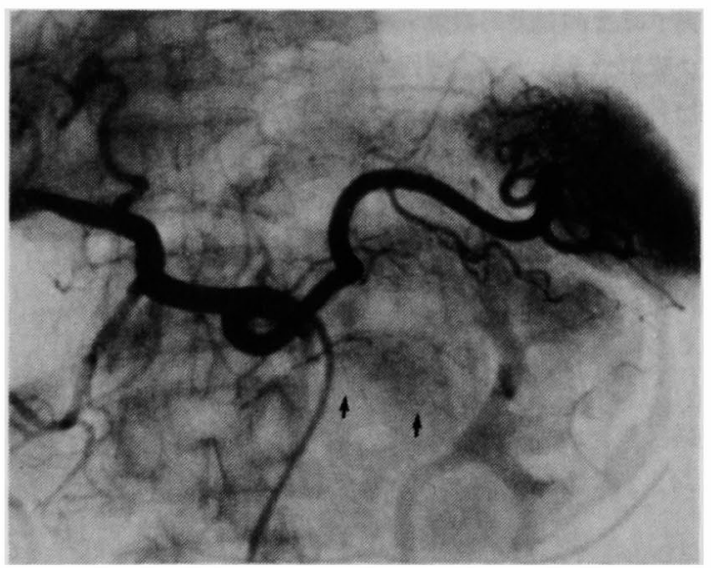

図 4 腹腔勤脈造影所見

背膵動脈より feeding された腫瘍血管の一部がみら れた。

静脈根部では左侧からの圧排像がみられた（図6）. 小渴二典造影所見

Treitz 畅帯㨁後と思われる空腸に軽度の 変形がみら れた。粘膜像に強い変化はないがこの部分の粘膜すう壁 に軽度の乱れがあり，また長軸方向にる粘膜变形がみら

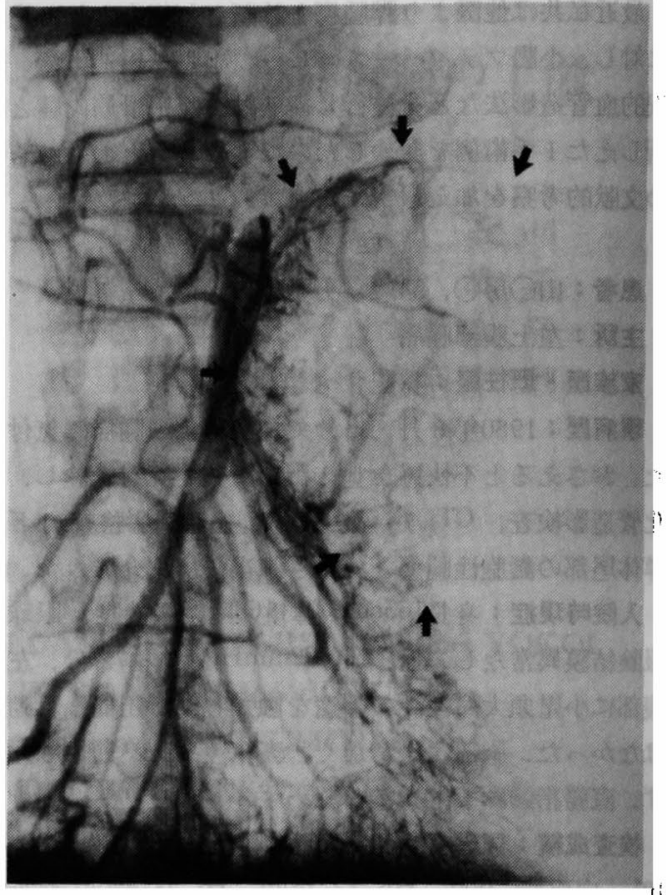

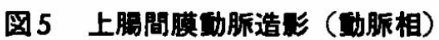

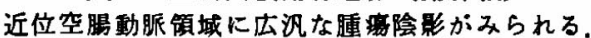

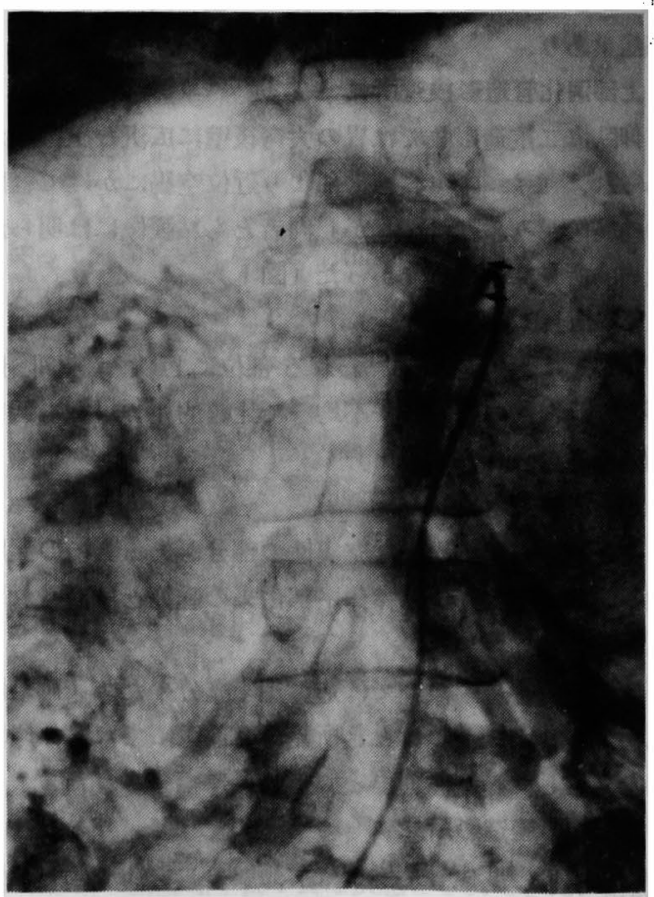

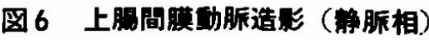

上腊間膜静脈根部左倒に軽度王排像がみられる。 


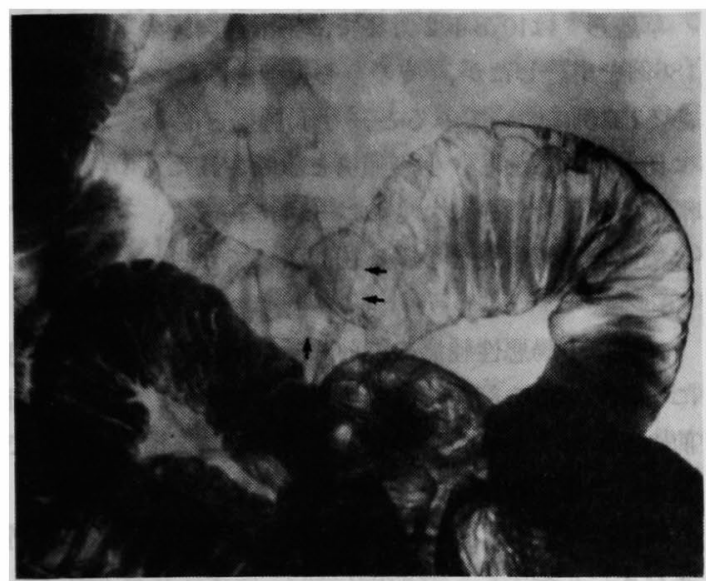

因 7 小渴二重造影所見

粘膜ナう壁に軽度の乱れがあり，長軸方向にも粘膜 像の軽度变形がみられた。

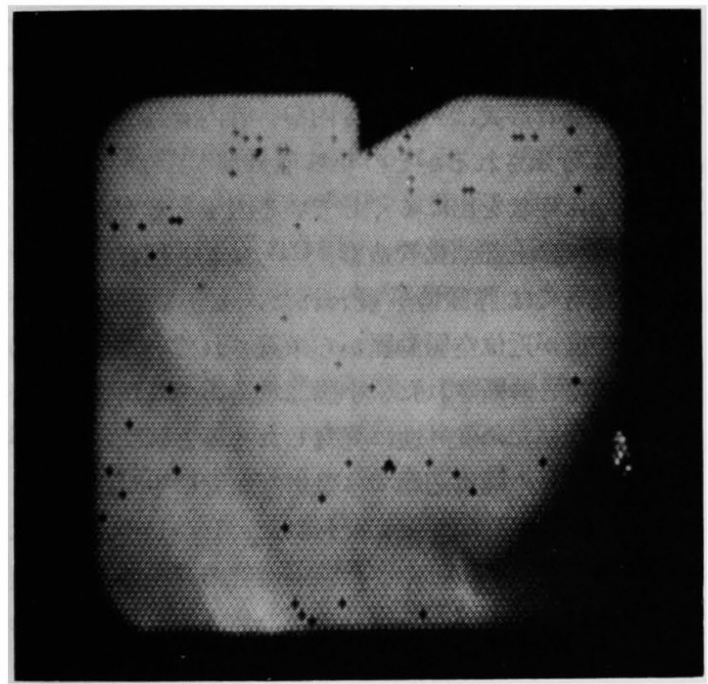

図8小閶ファイバースコピー所見

Treitz 政帯直後の空腸に軽度の粘膜下畽瘍様の膨隆 かみられた。

れた。いずれにせよこれらは壁外性の腫瘍による変化と 考えられた (図7)。

小渴ファイバースコピーの所見

Treitz 靬帯直後の空腸に軽度の 粘膜下腫瑒様の膨隆 がみられた。表面は正常粘膜で被れており，生検を施行 したが正常粘膜を採取したのみであった（図８）.

以上の所見を総合して殊に血管造影所見からは近位空 腸の壁外性に発育し中心部は壊死㑯向の強い平滑笳肉腫

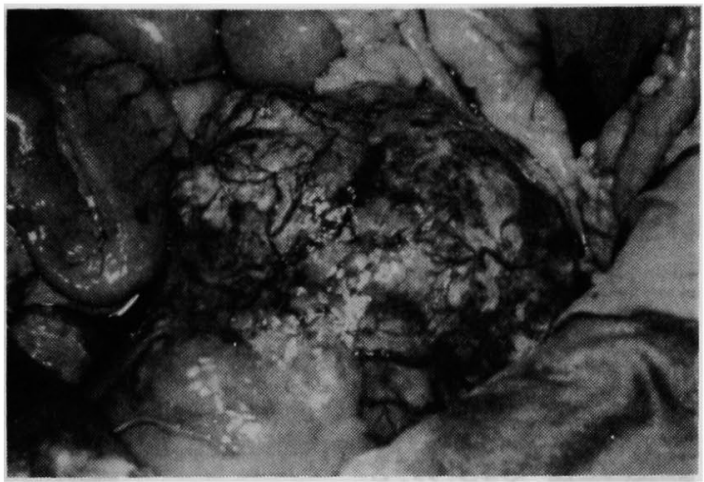

図 9 開腹時所見

董連粎の粎相を呈し，表面の血管は著しく怒張して いた.

と術前診断し，開腹手術を施行した。

\section{開腹時所見}

上腹部正中切開で開腹するに腹水なく，肫転移，腹膜 播秏等認めず，腫場は Treitz 鞋帯直後の空腸の腹間膜

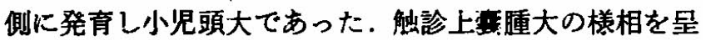
し被獏包まれ表面の血管は著して怒镸していた。 上方 は勝体尾部下緑に接していたが殆んど获着は認かず内側 は膵鈎部，上腸間膜動静脈根部と塺着していたが浸涺は なうそれらは容易に剥離しえた。従って Treitz 靶帯を 口側へ少し剿離し，睡場の近位約 $5 \mathrm{~cm}$ ，遠位約 $100 \mathrm{~cm} の$ 部分で隀㾨および腸間膜とよもに切断し端々吻合で再建 した (図9).

\section{摘出橒本肉眼所見}

腫掦は空腸壁より発生し腸間膜側へ照外性纪発育して いる．粘膜面は円形の軽度のひきつれがみられるが粘膜 そのものの変化はない，大きさは $14 \times 10 \times 8 \mathrm{~cm}$, 重量は $840 \mathrm{~g}$ であり割面を入れると内部は茨状の出血性壊死物 質が充满して放り実質性の部分は僅かであった（図10).

\section{病理組蔀学的所見}

腫瘍は大型の核をむつ紡錘形細胞からなり，腫汪細胞 は不規則に交錯し核異型も著明である. mitosis も多く 認められ空腸の固有竻曆より発生した平滑筋闪腫と診断 した (図11).

本患者は術後合併症るなく約 1 ケ月後に，退院した。 術後 7 ケを程過した現在外来に一 follow up 中である が再発の徽なく健在である.

\section{考按}

小腸原発の悪性腫晹の発生頻度け比洨的低く，特異的 な症状のないこと，解剖学的湖約から検查が困難なこ 


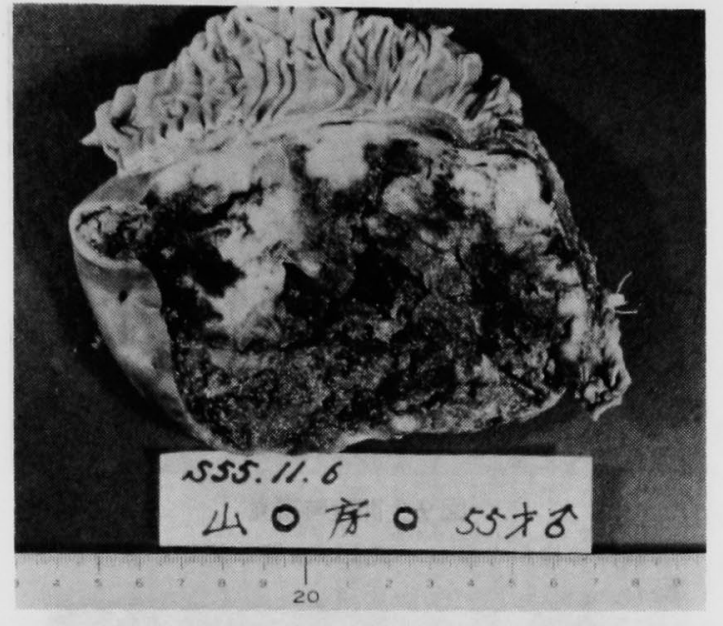

図10

腫㻛は空晹壁より発生し，腊間膜側へ壁外性に発育 している。割面は血性壞死物質で充満しており，実 質性の部分仕僅かであった。

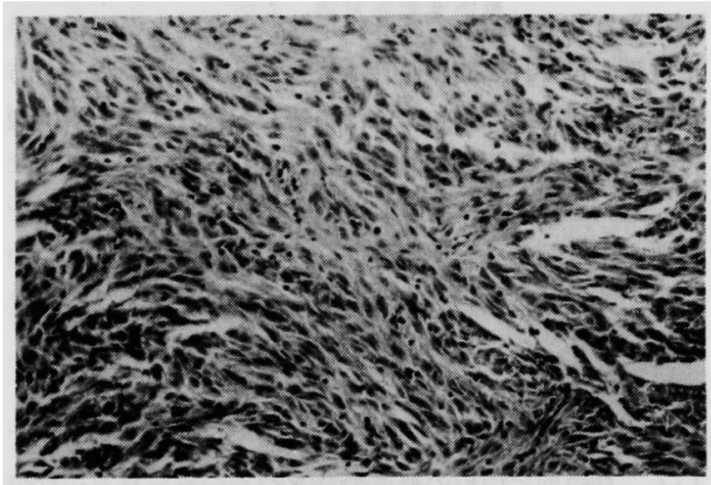

图11病理組学的所見

腫癌は大型の核をもつ紡鉏形細胞からなる，腫瘍細 胞は不規則に交錯し核異型も著明であり平滑管肉隀 の像である。

とまた諸家の認識のそしいことなどの理由により，従 来より術前診断の困難な次患とされてきた．しかし近年 小腸造影検査や血管造影検査なとの進歩とともに諸家の 小腸疾患に対する関心の高まりなとにより小腸悪性腫陽 についても本症例のことくかなり適確に術前診断がなさ れるよらになってきた。

小腸平滑筇肉腫の臨床統計学的な報告は近年比較的多 くの報告者によってなされているので私共はおすに本疾 患の診断について若干の文献的考察を加穴涘討してみた い.
草島ら”は1978年2月月でに平滑筋肉腫の本邦報告例 186例を集詰したが，そのうち術前診断について記載の ある137例についてみると，小腸腫焬と診断されたもの は16\%であるとし，小腸腫堭と診断されたものの中で平 滑筋肉腫と疑診されたものは 3 例に過ぎず，それらはす ぺて血管造影所見よ小腸透視によってなされたと墭告し ている.

一般に小腸要性腫瘍の術前診断は困難であり，他疾患 による開腹時や剖検時に僛然発見されたり，あるいは術 前に竝断がなごれてす開腹時にはすでに根治性の期待で きない程准行した掖例の多いのが現状であっだ．

癌腫についてはその病理学的特性から狭窄ないしは閉 塞をきたしやすく，比較的早期に臨床应状を是するこ とが多いが2゙ー5)，肉腫ことに平滑筋肉腫では汪とんどが 腫瘤型の発育をするため ${ }^{1) 6}$ 経過が潜行性であり，臨床 症状をきたしにくく，従って腫堭の壊死による消化管出 血や腸重嫧あるいは尰湯が高度に発育し腹部腫瘤を呈す るような状况になって診断されることが多い．また平滑 筋肉䏦の発育形式は一般に管内型, 管内管外型, 管外型 の3 型に分類されるがその5ち管外型16) 12)が多いこと む一層臨床拝状を壯にくくしている因子と龵えられる。

本症例では上部消化管造影，CT および超音波検查を

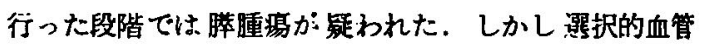

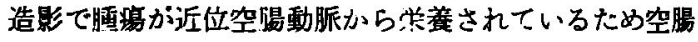
原発の腫湯と診断された，小腸二重造影では粘膜像に著 変を認めないため壁外性に発育した腫瘍と判断されたが 血管造影所見上腫瘍辺緑には豊富な血管增生が認められ

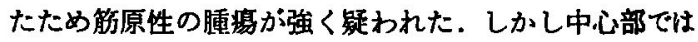
血管陰影のそしいこと、また隀陽血管の管径の不整な傾 向があるなどの所見から壤死傾向の強い平滑筋肉腫と誩 断された.

小腸平滑筋肉嗹の小腸造影所見については比較的多数 の報告例がみられる。一般に管内腫瘤型では病変が描出 されやすく陰影欠損像を示すむのが殆んよ゙である゙2)，し かし管外嗹瘤型では，本症例のごとく小腸造影険查では 軽㖪な所見にとどまるむのが多く，中心壊死により啺管 内腔上交通をきたしたような症例 ${ }^{831113)}$ を除いては一般 に小腸造影検查による訩断は困難である。

病理学的特性から小腸の癌腫の䛦断は小腸造影検㚗に より比較的容易であるが吕，平滑筋肉腫々腫嘴形成型の 悪性リンパ煄との爁別は造影検查では困難なことがあ り、この場合血管造影が有効となる。

小腸覀性腫湯に対して血管造影を施行した報告は梗め 


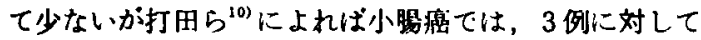
血管造影を施行し 1 例には庫韵血管や encasementなど の明らかな悪性所見を認めたが，他の 2 例については軽 度の腫珸染がみられたすのの明らかな悪性所見はみられ なかったとしている．著者ら ${ }^{(2)}$ る 例の小腸癌に対し血 管造影を施行し太去会らち 2 例飞 encasement, 中等度の

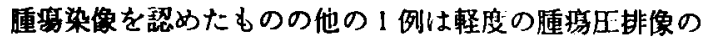
みであった。

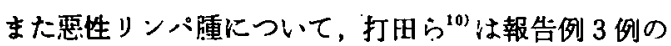
らち明らかな腫場血管がみられたのは1例のみで、他の 2 例には悪性と断定できる所見は認的られず，腸重積に よる血管の変位や、腫境による圧非像が主であったとし ている.一方小腸平滑筋腫場の血管造影所見については 前 2 者より此較的多数の報告例がみられるがいずれの報

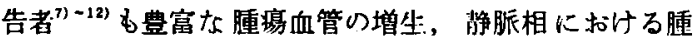

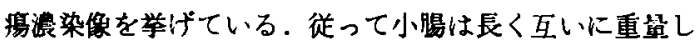
ているといら解剖学的特性とす相まって前 2 者, 殊に血 管そのものの変化にそしい恶性りンパ䛻では血管造影を 行っても病的所見が描出されがたいため血管造影が崄断 上の決め手となり難いと考えられる。一方平滑等腫湯は 㱠んどの症例で hypervascular な様相を呈するため病変 が描出されやすいこと之相まって胀器の局在診断のみな らず，前 2 者との鑑別上も有力な決め手となると考えら れる。

平滑笳腪場の良・悪性の篮別は一般に困難であるが， 打田ら ${ }^{100}$ は腫晹血管の不整佰向のあること，宫生動脈の みられることなどを悪性所見として指摘している。また 本症例の如く大きい腫瑒で，腫場辺縁は hypervascular であるにもかかわらず中心部の血管陰影のそしいるのは 中心壊死の所見であり ${ }^{12)}$ ，これ恶性と判断する因子と 考えられる.

また術前の確定診断の手段として最近では小腸つフイ ハースァーブも比䑤的活用されるようになった。不症例 にも街前小腸ファイハーースシープにより病变部の生検を 施行したが管外性発育を呈することもあり陰性であっ た。しかし捗例によっては生娭により確定診断の得られ る場合もあるので今後さらに活用したいと考えている。

$$
\text { 菬 語 }
$$

54葴 男子、腹部腫䈏を主訴として来院し上部消化管

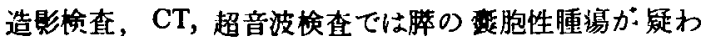
れたが，選択的血管造影検查で術前に空腸平沿第肉腫と 訩断しえた症例を経験した．本症例の診断経過ととるに 小腸平滑筇肉腫につき診断を中心として若干の文献的考 察を加え報告した。

\section{文裁}

1）草島義德，合知 圆，滕田秀春他：巨大空晹天 消等肉腫の 1 治験例一並ひに本邦小湯平滑等肉 腫186地の检討一，外科治療，42:503，1980.

2）穴沢＇（夫，鈴木正尔，綿貫 喆他：小腸腫堭に ふ・て, 癌の臨床, $21: 19,1975$.

3）中神一人，太田 敬，䗋頁筫喜多男他：空腸大 らひに回腸の悪性腫場11例の検封，外科，39： 353, 1977.

4）中神一人，太田 敬，蜂須貿喜多男他：小腸要 性腫寡の外科臨床および病理学的特性，日本臨 床外科医学会誌，39：127，1978.

5）工藤浩史，岸本芸之，竹重元寛地：原発性回腸 癌の 3 例一本邦報告例75例の統市十的観察一, 外 科, $39: 574,1977$.

6)武市 卓：消化管平消筋肉腫58例の臨床病理学 的研究，四国医誌。31：179，1975.

7) 高木 靖, 柏村征一，白相光康他：巨大な回腸 平消筋肉腫の 1 例，胃之腸，8：489，1973.

8）紊藤清二, 本間清和，斎藤征史他：小腸人視鏡 及ひ值視下生娭により衍前診断し得た空腸平滑 胳肉腫の一例. Gastroenterological Endoscopy, $19: 563,1977$.

9）小合孝之，上降美，東野正幸他：小腸肉腫の 3 例，外科診療， $17: 658,1975$.

10）打田日出夫，黑田知純，佐藤正之他：小晹疾患 における血管造影の診断的価値, 臨休放射線. $20: 533,1975$.

11）策田正昭：小湯平消箭肉腫の進展・発育につい て, 京都府立医大誌, $84: 917,1975$.

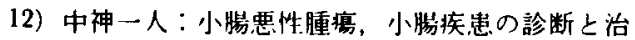
療一症例を中心として一，第 8 章 B：131，医学 四書出版，東京， 1980.

13）大平整爾，阿部慧剅，近滕正道他：X楾上，想 室像を示した空腸平消筋肉腫の 1 例，外科，37： 1084, 1975. 